\title{
Contributions Of International, Regional, National, Local Feminists And Women Organisation Networks To Women Development
}

\author{
Comfort Yemisi Afolabi, (Ph. D)
}

\begin{abstract}
The sufferings of women in the society and other acts of discrimination against women resulted in the rise of women or feminist movements worldwide especially in the Northern countries of the globe. As a result of the dehumanization of women in most communities of the world, many activists and women movements evolved to proffer solutions to women and gender issues. This paper examined the contributions of international, regional, national and local women's movements to development. The paper delved into the Waves of Feminism which made various changes and resulted in major freedom and development for women in education, family life, health wise, employment and politics. It looked at the importance of women to economic development. Various women's movements and networks were discussed. Challenges of these women's movements were identified and recommendations were made. The paper employed secondary sources for information for the study.
\end{abstract}

Key Words: Development, contributions, feminism, patriarchy, women, movements, networks

\section{INTRODUCTION}

Development is about growth, it's about expansion and it's about getting better and becoming stronger in all spheres of the society. Development is the systematic use of scientific and technical knowledge to meet specific objectives or requirements. It is the process of economic and social transformation that is based on complex cultural and environmental factors and their interactions. The key areas of targets when development comes to mind include how the development is expected to happen. It shows that development will come when knowledge is accurately utilized. Development is based on complex cultural and environmental factors and their interactions. Development is not one sided not from one end but from different angles. Development according to Webster-Merrian (2003) is the process or act of gradually becoming bigger, growing or causing something to grow or be better, stronger, or more advanced.

Every member of the society regardless of their gender, age or class has different roles to play in development. Development processes is a system. The truth is that, if any of the parts of the society is not contributing its quota, the quality of development achieved will be adversely affected. Unfortunately, our society had been immersed by patriarchy, sexism and gender discrimination, thereby, making development one sided and incomplete.

Women from the beginning of feminism, campaigned for women's rights including the rights to education, vote, work, earn fair and equal pay with men for equal job, hold public office, own property, enter contracts, equal rights within marriage and enjoy maternity leave. Feminists have also campaigned and worked tirelessly to promote women bodily and integrity, protect women and girls from rape, sexual harassment and domestic violence (Echols 1989). These activities of women had enhanced women's development. If a woman is developed, her family, 
including her children are likely to benefit from her development. Thus, the whole nation will enjoy development on the long run.

The formation of women's movement was not human rights and ecological movements. Women movements achieved monumental changes for the rights of women and global development. According to Messer-Davidow (2000) women campaigns and movements were part of the main forces behind major historical societal changes for women's rights, having achieved women's suffrage, gender neutrality and reproductive rights for women including access to contraceptives and abortions, the right to own property and be part of development. This paper aimed at highlighting the important roles that women's movements have played and can still play in social, economic and political development.

\section{THE WAVES OF FEMINISM AND THEIR ACHIEVEMENTS}

There were three main waves of feminism though a fourth wave of feminism was identified by some authors. The waves of feminism dealt with the suffrages of voting rights, working conditions, education rights for women/girls or the girl child among others (Ogundana 2015). There had been a lot of advocates against the discrimination suffered by women but an organized women movement started with the coinage of feminist by Charles Fourier in 1837 (Goldstein 1982). Feminists appeared in France and the Netherlands in 1872, Great Britain in 1890s and United States in 1910 (Offen 1987 and Cott 1987). The words Feminists and Feminism were coined to refer to those fighting for the rights of women and their ideologies respectively. Based on their historical movement, culture and country, feminists worldwide had different causes and goals. The history of modern feminism or women movements was divided into three waves (Humm 1995 and Walker, 1992).

\section{First Wave of Feminism}

The first wave comprised women suffrage movements of the $19^{\text {th }}$ and early $20^{\text {th }}$ Centuries, promoting women's rights to vote (Krolokke 2005). The main concern of the women movements under the first wave were women's education, employment, marriage and the plight of intelligent middle class women. According to Freeman (2003), in the United Kingdom and United States, the first wave focused on the promotion of equal contract, marriage, parenting and property right for women. By the end of the nineteenth Century, the focus was primarily on political power, particularly, the right of women suffrage while some women activists were already campaigning for women's sexual, reproductive and economic rights.

In Britain, under the first wave, the suffragists campaigned for women's vote and in 1918; the representation of the peoples' act was passed granting the voting right to women over 30 years of age who owned houses. This was extended to all women over twenty-one years in 1928 (Phillips 2004 and Australian Electoral Commission 2011). In Britain, Emmeline Pankhurst was the most notable activist (Warner, 1999). In the United States, notable leaders of women movement included Lucretia Mott, Elizabeth Cady Santon and Susan Betty Anthony who campaigned for the abolition of slavery prior to championing women's rights to vote. These women activists were influenced by the Quaker theology of spiritual equality which stated that men and women were equal under God (Radford, 2012). Patriots such as Susan Brown, Lucy Stone Anthony and Sojourner Truth travelled the country for the next 40 year (1848-1888) trying to convince people that women's rights should be recognised. As a result of the efforts of these feminists, there were many achievements in Britain, United States of America, Russia, Germany and China among others (Pond 2011, Ruether 2012, Rampton 2014 and Ogundana, 2015). 
The major achievements of the first wave according to Freedom (2003); Dubois, (1997); Flexner (1996); Wheeler (1995); Stephens (1995); Dooling (2005) and Ogundana (2015) included:

i. Opening of higher education for women'

ii. Reform of the girls secondary school system including participation in formal education, explaining the widening of women's access to the professions especially law and medicine. They achieved reforms for girl's education;

iii. Married Women Property Right was recognized. In the Property Act in Britain in 1870 , it was there on paper but not recognized;

iv. There were some improvements in the Divorced and Separated Women's Custody Rights of Children Act;

v. In 1920, the right to vote was granted to women, exactly 144 years after the legislation/law had granted it to men;

vi. It was in 1965 that married couples in all the States obtained contraceptives legally and the Court declassified its distribution. It took another 29 years to achieve this feat. The fact that they were able to obtain contraceptives did not mean that they have the right to abortion;

vii. The right to abortion was granted in 1973;

viii. In Russia, in 1913, women observed the First International Women's Day on the last day on the last Sunday in February. But celebrated in Soviet Union, May 1917, Austria, Denmark, Germany and Switzerland in 1919, China in 1922, Spain, 1936, and in the West, after 1977 at the UN General Assembly when the date was changed to $8^{\text {th }}$ March and it has remained a global day for women (Sydney Morning Herald, (1943) and Nelson, (2011);

ix. These incidents in England made Marie Charlotte Carmichael Stoops $\left(15^{\text {th }}\right.$ October 1888-2 $2^{\text {nd }}$ October, 1958) who believed in equality in marriage and the importance of women sexual desire to published 'Married Love' in 1918 and according to a survey of America Academic, the book was one of the 25 most influential books then;

x. In Germany, the right to vote was granted to women in 1919;

xi. In England, Nancy Aston became the first women to take her seat in the House of Common in1919;

xii. In China, the first female set of students were accepted in Peking University and soon followed by Universities all over China. The feminists during the first wave campaigned for legal and social equality for women (Krolokke 2005).

\section{The Second Wave of Feminism}

The second wave or movement was dedicated to raising consciousness about sexism (superiority of a sex over the other) and patriarchy (Men having authority over women in properties and resources in the family); legalising abortion and birth control; attaining equal rights in political and economic reams; gaining sexual liberation in the sense of women turning down their husbands'/men's sexual requests.

The second wave was associated with the idea and actions of the women's liberation movement beginning in the 1990s. The second wave campaigned for the legal and social equality for women (krolokke and Sorensen 2005). In Britain, the second wave was multiple in focus, although, it was based more strongly on working class socialism as demonstrated by the strike of women workers in the company for equal pay in 1968. The slogan was of 'Personal is Political' and this wave identified politics in an effort to show that race, class and gender oppression are all related (Rampton 2014). Some of the wave's feminists did not just strive to make impact on the Western societies; they expressed extension of the range of social opportunities opened to women. They did this through intervention in the spheres of 
reproduction, sexuality, cultural representation and the need to change domestic personal life. The second wave feminists saw women cultural and political inequalities as inexplicable and that it encouraged women to understand aspects of their personal life as deeply politicized as reflecting aspect of sexism. The second wave feminists did not just make an impact on the Western societies but had also continued the struggle for women's rights across the world (Ogundana 2015).

In America, the second wave feminism arose out of the civil rights and anti-women acts of domination/discrimination. Women were disillusioned in their second class position even in the activists' environment of student politics. The tactics employed varied from highly published activism such as protest against beauty contests in 1968 to the establishment of small consciousness raising groups. This movement's protest was not a unified one - no concession because of different factions of feminism such as liberal, radical, black, lesbian, social, Marxist, cultural feminism (Baumgardner and Richard 2000 and Ogundana 2015). The main gains of the second wave among others according to Ko, Haboush, Piggott (2003); Echols (1989); Whelehan (1995); Baumgardner and Richard (2000); Hanisch (2006); Pond (2011) and Ogundana (2015) were:

i. The Commission on the Status of Women was created in John Kennedy's Administration and Eleanor Roosevelt was elected in 1963 as the chair. The report of the Commission documented the discrimination against women in all areas of their life;

ii. In the same year, 1963, a book by Betty Friedan Ann 'The Feminine Mystique' appeared on the book shelves which contained interview materials which buttressed the fact reported by the earlier Commission Report. It became an immediate best seller;

iii. Consequent upon combined efforts of many feminists/activists, the Title VIII of the Civil Right Act of 1964 was passed. The Act forbade discrimination on the basis of sex, age and national origin.

iv. Eight (8) years later, (1972), Title IX in the Education Code/Law was passed. The Title is also important to young women today because of its contributions to provision for women's sports in school and feminists campus activism among other things. It should be noted that many of the anti-discrimination existed in name only, for example, within the Commission's first 5 years (1963-1968), it received sex discrimination complaints but did nothing to address them.

v. The National Organisation for Women (NOW) was formed in 1996 by 29 women among them was Betty Friedan Ann. NOW mission was to function as a legal watch dog. This was also followed by other organizations such as American Radical Organization Red Stoking in 1969 and in 1973- American Black Feminists Organization. These organizations were directed to address the specific needs of groups of women including Asian, Blacks, Lesbian, Business Aspiring Politicians and others.

vi. In January, $22^{\text {nd }} 1973$, through the passage of the case of Roses versus Wales by the United State Supreme Court, abortion became legal in all 50 States of America. The right to decision to have abortion was consistent to right to privacy under the $14^{\text {th }}$ amendment to the constitution of America.

vii. The waves began in 1980 in Turkey and Israel.

viii. Inspired partly by the legal victory of $60 \mathrm{~s}-70 \mathrm{~s}$ but still worried about the de - facto discrimination, feminists worked to ratify the Equal Rights Amendment (ERA) as part of the United States' Constitution. In fact, the amendment that was effected in 1942 stated that 'Equality of rights under the law shall not be denied or abridged by the United States or any other State. However, as at the time, there were 
presentations for ratification in 1982, the ERA was just three (3) States short of the 38 States needed to get it entrenched into the United State Constitution - it was not ratified'. It should be noted that the defeat of the ERA signalled one out of three things: firstly, a prove that a new era within second wave feminism must begin; secondly, a sign that $3^{\text {rd }}$ wave must begin; and thirdly, prove that they were then in Neo-Conservative Era (Post- feminism) along the opinion of Christian Sommer's work called "Feminism is no longer necessary".

\section{The Third Wave of Feminism}

The third wave began in the 1990s as a response to the perceived failure of the second wave. The third wave was more of an expansion of the second wave but focuses on new directions. The second wave appears not to meet the needs of large body of women since women did not have the same needs. It was criticized to only essentialised the needs of white and middle class who led the second wave. Based on these criticisms, the third wave focused on goals of people who had been voiceless. It was to meet the needs of the voiceless. So, specifically therefore, the needs of the third wave of feminism emerged (Gills, Howie, Munford eds, 2007 and Faludi, 1991). According to (krolokke and Sorensen, 2005), the $3^{\text {rd }}$ wave was the continuation and a reaction to the perceived failures of second wave feminism of women movement beginning in the 1990s. Rebecca Walker coined the term third wave feminism in a 1992 essay. She was a symbol of third wave's focus (Snyder, 2008).

When feminism moved into Colleges and Universities, feminism became even more shattered as different political, intellectual and pedagogical interests became more attracted to it. Also, many feminists movement emerged such as Psycho Analytical Feminism, Marxist, Radical, Liberalism and Cultural Feminism. Feminism became not just a political movement but ideology with unique distinction to make it to be even more complicated. It was possible to be ideological feminist but not politically feminism inclined (O'Neill, 1969, Cott, 1987, Rupp and Taylor, 1987). As feminism became increasingly academic discipline, it loses the ability to connect to the lives of average women in language, accessibility and in context. It focuses on inequalities that women face based on age, sexual orientation, level of education, economic status, and race. By empowering women, it was building a lasting foundation for social activism around the countries of the world, however, they have problems. The third wave feminism was powered by middle class women in their 20s and 30s i.e. the wave of the youths (Lamb 2009 and Ogundana 2015).

The third wave had built a lasting foundation for the social activism around the countries of the world. The problem was fighting their course. There were criticisms, especially that those that were trying to revive third wave have done nothing to change things politically especially because of their involvement in what Nancy Fraser called counter public sphere and places not usually understood (Pond 2011). It was linked to rationality and change. Although, they may hold demonstration from time to time, third wave was active in arena like cultural and the critique of cultural feminism for example; they wore makeup and acknowledged participation in beauty pageant even when they condemned it while the second wave stated that 'the Personal is Political', the third wave sated that 'the Pleasurable is Political'. Perhaps, the third wavers were more influenced by such as Bell Hooks. Hooks was indeed considered a key figure for many third wavers because her complex analysis of entertainment forms and types (which other people said was not political) reveals issues of race, globalization and desire of young women today (Walker 1995, Ogundana 2015, Baumgardner and Richards 2000, Newman 2012). 
The fact that many third wave feminists were well aware of the important criticism of the second wave for being too closely aligned with white women politics complicated and aided further division between academic and mainstream feminism. Maybe it was not that the third wave feminists were not political but that the political struggles of influence were not directly tied to American movement. For example, the third wavers were interested in women musicians/ festivals while also voicing concerns of trans-sexual policy. Many third wavers saw women issues as global issues such as sexual discrimination and Beijing Conference on changing women's rights violation. Even more important was that countries' participation in culture and industry often put others at risk, like China known to be involved in child trafficking to get diamonds used for engagement rings (Ogundana 2015). The achievements of the third wave among others according to Freeman (2003); Douglas \& Douglas (2010); Astrid 2004; Gillis, Howie \& Munford (2007) and Ogundana (2015).included:

i. Acceptance of gender equality in education in 1994. The Equal Education Act became a law in the United State. This law banned sex stereotype and gender discrimination in the class room. In 1994, violence against women was renounced;

ii. In 1995, the $4^{\text {th }}$ World conference on women was held in Beijing, China;

iii. In 2004, the gender equality and the Equality Act came into effect in the United Kingdom;

iv. In 2006, Nigeria developed a National Gender Policy for implementation in the country;

v. In 2008, Norway required Oil Companies to have at least $40 \%$ of their board members as women.

\section{WAS THERE A FOURTH FEMINISM?}

The fourth Wave started from 2008. In America, a critical mass of younger feminists began expressing themselves. They were gender-sophisticated. Their youth was shaped by the 1980s backlash, Take Our Daughters to Work Day initiatives (also known as the Girls' Movement, led by Second Wave women) of the '90s. Perhaps most significant, though, their experience of the online universe was that it was just a part of life (Bamgardner 2011).

Much like the Third Wave, the $4^{\text {th }}$ Wave lived out the theories of the Second Wave (with sometimes surprising results), the Fourth Wave enacted the concepts that Third Wave feminists had put forth. Drawing from their own experiences, young activists created afterabortion talk lines to enable women and men to get the support they needed after a procedure-no enforced political line included. Trans-health initiatives (like that at the Feminist Women's Health Centers in Atlanta) and trans-inclusive organizations like Third Wave Foundation (helmed by feminists in their twenties and thirties) reinforced the potential for all people to access feminine and masculine genders (Bamgardner 2011).

In place of songs, young feminists created blogs, Twitter campaigns, and online media with names like racialicious and feminizing, or wrote for Jezebel and Salon's Broadsheet. They commented on the news, posted their most stylish plus-size fashion photos with info about where to shop, and tweeted that they, too, had had an abortion. "Reproductive justice," coined by women of color in the 1990s, became the term of choice for young feminists. Transgenderism, male feminists, sex work, and complex relationships within the media characterized their feminism (Bamgardner 2011 and Ogundana 2015).

The fourth wave was the emerging agitation not currently acknowledged as historical wave. Pithipon-Piey (2000) and Baumgardner (2011) have advocated for the existence of the fourth wave due to the lack of activism in the other waves of feminism regarding new historical issues. Feminists who currently advocate for a $4^{\text {th }}$ wave belief that the circulation of feminists' issues should rely on social media issues for communicating their criticism effort which means 
that fourth wave was largely defined by technology. In 2012-2013, in the United Kingdom and some other nations of the world, activism in the context of the $4^{\text {th }}$ wave was active. Cochrane (2013) noted that the fourth wave focuses on inequality manifesting in street harassment, sexual harassment, work place discrimination, assault in public places and inscription on Tshirts with feminists' messages among others. All these issues were handled by these feminists' actions. Women were encouraged to desire their sexual attainment towards masturbation (as a way of rejecting the pleasure stand which they believe third wave feminists stand for).

\section{IMPORTANCE OF WOMEN MOVEMENTS TO ECONOMIC DEVELOPMENT}

The most influential evidence on the importance of women to economic development came from research used to support the World Bank's 'Gender Mainstreaming Strategy' launched in 2001 (Dollar and Gatti 1999; Klasen 1999). The research opined that societies that discriminate by gender tend to experience less rapid economic growth and poverty reduction than societies that treat males and females more equally, and that social gender disparities produce economically inefficient outcomes (World Bank 2001a). For instance, it is indicated that if African countries had bridged the gender gap in schooling from 1960 to 1992 as quickly as East Asia did, this would have produced close to a doubling of per capita income growth in the region (WBGDG 2003).

The major pathways through which gender systems affect growth are through influencing the productivity of labour and the efficiency of the economy (World Bank 2002). In terms of productivity, for example, if the access of women farmers to productive inputs and human capital were on the same path with men's access, total agricultural output could increase by an estimated 6 to 20 percent (World Bank 2001b). Identification of women as being a reliable, productive and cheap labour force makes them the preferred workforce for textiles and electronic transnational corporations. Perception of women as being prudent, including being better at paying back loans, has led them to be targeted in microfinance programmes. Recognition of women as more efficient distributors of goods and services within the household has led to them being targeted with resources aimed at alleviating poverty, such as cash transfer programmes. These show how the justification for including women in development in economic growth has been an efficiency argument, with equality and equity concerns being only secondary. In the 1970s, research on African farmers noted that, far from being gender neutral, development was gender blind and could harm women. Out of this realization emerged women movements at various stages from international to local levels. These women organizations have worked immensely to develop other women to enable them play key roles in the development of their various societies (World Bank 2001b).

According to Development Alternatives for Women for new Dawn (DAWN) (2019), through case studies for the three most populous countries of Asia, DAWN, examined what policies and programmes worked and what have not challenges that needed to be addressed in order to move Sexual and Reproductive Health Rights (SRHR) agenda forward. In addition to government approaches and action, DAWN also examined the roles of other stakeholders such as international agencies, private functions and philanthropists, governmental organisations and social movements, as well as regional, local governments and other bodies where possible and relevant. These case studies foreground human rights through the Equality, Quality and Accountability lens and the ways in which these could be built into SRHR agenda at country level policies and programmes to enable operation and fulfilment of International Conference on Population and Development (ICPD) programme action; Beijing Platform for Action; Sustainable Development Goals and Universal Health Coverage in commitments and to overcome ongoing lacunae and barrier. 


\section{INTERNATIONAL WOMEN ORGANIZATION NETWORKS AND DEVELOPMENT}

Women's groups have done a lot to enhance development of women worldwide by their group activities. Women were very active in deliberations on the rights of women and development. Several women came together to deliberate on how to involve the women folk all over the globe in development of their societies. Commonwealth of Learning (2000) reported that seventeen women were among the delegates at the founding meetings of the United Nations in San Francisco in 1946. The setting up of a Commission on Human Rights was discussed. The meeting decided that the rights of women were not given the priority that they deserved. The Sub-commission on the Status of Women was then set up. Later, a full-fledged Commission on the Status of Women was agreed upon because women were dissatisfied with a Subcommission.

The first meeting of the United Nations Commission on Human Rights (UNCHR) had its first meeting in January, 1947 while the United Nations Commission on the Status of Women (UNCSW) had its first meeting in February, 1947. The UNCSW placed women's rights firmly on its agenda despite insufficient funding (Commonwealth of Learning, 2000). Two years before the United Nations World Conference on Human Rights in Vienna in 1993, women held worldwide hearings on violations of women's human rights and collected more than 500,000 signatures on petitions demanding that women's human rights issues including violence against women, should be placed on the conference agenda of the UNCHR and not just by UNCSW which was not adequately funded but also lack the official protocol to deal with violations of women's human rights. Women requested for a tribunal on crimes against women and the appointment of a Special Rapporteur on violence against women (Commonwealth of Learning, 2000). The United Nations had played major roles in making women international movements and to portray women's rights as human rights. Women movement have used the opportunities provided by four UN World Conferences on women in 1975, 1980, 1985 and 1995, the official ones and the alternative Non-Governmental Organisation forums, as arenas in which they set goals, plan, network and inspire one another to continue their work (West 1999).

During the centennial celebrations in 1994-95, the World Young Women's Christian Association (YWCA) recorded the history of 100 years of women's intervention and activism on women's issues and concerns. This organization held a special position in the history of women's movement. At the early years of this organization's history, women set up autonomous national Young Women's Christian Association (YWCA) groups in Africa, Asia, Latin America and the Caribbean and later in the Pacific. These groups planned and built permanent headquarters for their programs. This gave women a kind of stronghold, which they themselves control, in more than 80 countries. The national YWCA organized activities such as training, health, non-formal education, human rights, public affairs, energy and the environment and other community social work for women (Commonwealth of Learning, 2000). The YWCA trained women for jobs in the community and positions of leadership in all facets of the organization. This created a core opportunity for women leaders who often go on to become leaders in other parts of community life. Each national Young Women's Christian Association (YWCA) had complete control over management, programme, and future directions. The world office provided a set of guiding principles and, when requested, support for fund-raising and leadership-training opportunities were rendered. Many women on national delegations to the United Nations gained their leadership training and experience as committee or board members of the YWCA in their respective countries.

What helped the group in influencing the development of communities and providing other forms of activism was their central building and trained staff. Women were given the 
opportunity to be managers, trainers, decision makers and planners in an atmosphere that was women centered, nonthreatening and safe. According to Commonwealth of Learning (2000), this led to various achievements which included but not limited to;

i. The beginnings of political movements for more democratic societies;

ii. The introduction of appropriate technologies for women in rural and semi-urban areas;

iii. New and innovative training methods for women with little or no educational background;

iv. Participatory forms of group organizing; and

v. A host of other activities that have moved women into the forefront of development, both within their countries and around the world.

Commonwealth of Learning (2000) noted that since the United Nations International Women's Year (1975) and the subsequent Decade for Women (1976-85), international women's networks emerged to fill a need that women's groups had for better contact with others and for access to information and resources. Best known among these networks are Isis International (Manila and Santiago), Isis Women's International Cross Cultural Exchange, the Women's Features Service (India) and the International Women's Tribune Centre (IWTC). Neither the Isis groups nor IWTC have affiliated members that belong to the World YWCA and other more established international NGOs (for example, the World Association of Girl Guides and Scouts, the International Federation of Business and Professional Women and the Associated Country Women of the World (ACWW). The Women's Features Service came out of the Inter Press Service and functions as a news wire service, providing news. According to Commonwealth of Learning (2000), both IWTC and the two Isis groups undertake training and technical-assistance activities on request, and collaborated with national and regional groups to develop manuals, guidebooks, bibliographies for other women or gender development resource materials. Women had also been trained on the use of technology and computer applications for their jobs and other development activities. From the above, it could be seen that international women organisation networks had made substantial contribution to women development globally.

\section{REGIONAL WOMEN ORGANIZATION NETWORKS AND DEVELOPMENT}

Very little has been written about the history of the regional women's organizations and networks. Perhaps an exception is the Women and Development Unit (WAND) of the University of the West Indies in Barbados. Women and Development Unit grew out of a regional conference held in Jamaica in 1977, where women's groups from across the Englishspeaking Caribbean gathered to draw up a plan of action for women in their region. One of the needs expressed at this conference was for a central agency to provide resources, technical assistance and training for women's groups and projects. This kept isolated women's groups a little more in touch with other women's movement (Commonwealth of Learning, 2000).

In the Latin America and the Caribbean, the progress on women issues was very slow which was mainly due to military dictatorship in the region. There was no regard for women's rights to decision making in these countries. However, a few activities were organized by feminist women groups in Colombia in 1981(Commonwealth of Learning, 2000). Encouraged by the progress of the women networks, 200 women participated in a four-day debate and made plans of action and agreed to hold meetings in every two years in different Latin American Countries. In 1983, about 7,000 feminists from the region turned up to travel to Lima and Peru and they were able to make plans and decisions to strengthen the feminist movement in the region. At meeting, two years later, plans were put in place to accommodate the crowd of about 10,000 women who attended the Sao Paulo and Brazil meeting. Feminist movement in the Latin America grew gradually from the small beginnings in Colombia. More women began to 
participate in political campaigns and assumed positions of authorities in local and national councils. They became informed about women's rights and equality under the law. Feminist in Taxco, Mexico (1987), Mar del Plata, Argentina (1990) and El Salvador (1993) consolidated the feminist cause. The region was able to get rid of military dictatorships in 1995 in the region which could partly be linked to the efforts of these women movements among other efforts (Commonwealth of Learning, 2000).

The regional women networks have achieved a lot in the development of media channels in many regions by their developmental programmes for women in various regions of the world. The regional women's networks, especially those concerned with the flow of information within regions, have grown in importance during and since the United Nations Decade for Women. Women's regional media networks were found in every world region, especially, Africa, Asia and the Pacific, Europe, Latin America and the Caribbean, the Middle East, and North America. They operated within the framework of alternative media, sending their information directly to women's groups. Increasingly, these networks crossed over into the world of mass media and mainstream media channels (Commonwealth of Learning, 2000).

\section{NATIONAL WOMEN ORGANIZATION NETWORKS AND DEVELOPMENT}

The National Councils of Women (NCWs) have been foremost among national women's organizations and networks. National Councils of Women were usually set up to unite the efforts of national women's groups to lobby government or to improve facilities and programs for women in their country. Over the years, NCWs have had mixed reviews. Combining the efforts of national women's groups that have sometimes had long history in a country before the inception of National Councils of Women was not easy. But most of the member groups of National Councils of Women came together when there was a common cause, such as the need to develop a national plan of action for women or to promote legislation on issues related to women's human rights (Commonwealth of Learning 2000).

The Restocking Movement which was founded in the 1960s generated a national debate about the dominance of men over women in the family, workplace and political arena. In view if this, they contributed to a cultural shift that led to the support for quotas on political party lists, women's Centres and domestic violence shelters, women's studies programmes and spread welfare services. One of the contributions was that the national government was less dominated by men. Danish women made up 37.4 percent of the parliament which was the second largest at that time in the world (International encyclopedia of marriage and family, 2003). Denmark joined the European Union (EU) in 1973, though, the Redstocking opposed it (Walter 2001).

In most countries in the world, violence against women was a national disaster around 1980s and some women came together to discuss the problem in other to proffer solutions to the malaise. A multifaceted plan was conceived. According to Commonwealth of Learning (2000), information was placed in front of the countries at large to give everyone a clearer picture of the situation and just how it was violating the rights of women and damaging the very fabric of the nations. There was the need to educate men and women about the rights of women and to see more clearly that violence was never the answer to problems in the home or nation. Governments were lobbied to pass legislation that would give women some protection against the violence that they were experiencing. Women also needed safe houses and refugees camps where they could go in other to escape beating. The Tanzania Media Women's Association (TAMWA) was formed during such women's meeting. TAMWA has a regular newsletter, a Resource Centre, a Crisis Centre and a Refugee Centre for Women and other facilities. Several 
laws were passed to strengthen the rights of women and women lawyers joined the effort to end violence against women.

In Brazil, between 1964 and 1985, the country experienced repressive regimes and impoverishment along with the largest, most diverse, radical and successful women's movement in Latin America (Alvarez 1990). The success lay in addressing both women's strategic and practical gender needs. These strategic gender interests which included overturning the gender division of labour, gaining control over one's own reproduction and attaining legal and political equality have emerged from various analyses of the roots of women's oppression. Health care, nutrition and shelter, potable water and secure livelihoods, vital to the more immediate survival of women and their families, typified the practical gender interests that women hesitated to sacrifice for more long-term strategic gender needs (Molyneux 1985). According to Alvarez (1990) in Brazil and Latin America generally, strategic gender interests inspired feminist movements, whereas feminine movements focused on practical gender interests.

The Maendeleoya Wanawake was the major national women's organization of Kenya. Maendeleo had member groups in every town and village, an impressive headquarters in Nairobi, and a full-time staff of administrators and trainers. It undertook projects in a wide variety of areas and had been responsible for village water-pump projects, schemes for craft production and marketing, workshops for leadership training and a multitude of other rural and urban development activities with, for and by the women of Kenya. Increasingly, Maendeleoya Wanawake became involved in political and government activities, in addition to its programs for training and project implementation and this provoked a lot of debate on the roles and responsibilities of women in Kenya. Maendeleo was a member group of the Kenyan National Council for Women (NCW) (Commonwealth of Learning 2000). Also, Friends of Women (FOW) project was set up in Thailand by women concerned about the rising numbers of young girls and women lured from villages to work as prostitutes in Bangkok. The women of FOW set themselves up in a couple of rooms in the centre of Bangkok and began to make contacts with groups and individuals across the country and region and eventually with groups in other countries around the world. Their efforts and continuing concern for the welfare of young women in Bangkok became a national network of people fighting against violations of women's human rights and specifically against luring girls from poor families into a life of sexual slavery (Commonwealth of Learning 2000).

Friends of Women (FOW) Movement was not just a lobbying group, however. It provided counseling to young girls and their families, both in the village and in town; workshops for young leaders and helpers; resource materials, including flash cards and posters for group sessions; and a newsletter, which was published in both Thai and English. It was a network for anyone interested, rather than an organization, because it did not require membership and its activities focused on needs as they arose, rather than on any set programme (Commonwealth of Learning 2000).

In Nigeria, women associations were formed within the communal groups even before colonization. During the struggle against colonialism in 1947, the first national women's organization, the National Women Union was established and it was headed by Funmilayo Ransome-Kuti (Abdullah 1995). Since, 1960 when Nigeria gained independence, most women's movements or associations have continued to be tied to kin, ethnic, religious or national groups. Many women were also members of women's coalition such as the National Council of Women's Societies (NCWS). Before the British colonized the country, the Yoruba and Igbo women in the Southern Nigeria had powerful political roles within dual-sex systems of female 
and male authority. These women associations were based on trade, age and kinship. Women's movement organizations in Nigeria continue to value the complementary sphere of women's and men's interests, an idea reflected in the strategy of Nigerian women's groups to demand reserved places for women in political offices (Okonjo, 1994).

The national Council of Women Societies (NCWS) in Nigeria was founded in 1958 and the Council included more than 300 women's group under its umbrella. They relied on governments' support for their activities. NCWS priorities were to create more economic and political opportunities for women by promoting their education and training, legal equality in the public sphere and proportional representation. However, NCWS challenge was that it could not develop consensual goals. It was not able to address the issues of child custody, property rights, marriage, divorce and sexuality. These were threatening to men's customary authority in the family and Islamic law (Sharia), governing family law and practice in northern Nigeria (Okonjo, 1994). According to IEMF (2003), in Nigeria where religious divisions have fanned the flames of the civil war, NCWS's strategy was understood. This implied that leadership for change in familial customary and religious law came from autonomous women's organization, Nigerian representatives of transnational non-governmental organizations and women's human rights' organizations.

Friedan and Murray (2020) noted that the National Organisation for Women (NOW) was established to take action to bring women into full participation in the mainstream of American society, thereby, exercising all privileges and responsibilities thereof in truly equal partnership with men. The 6 core issues addressed were abortion and reproductive health services access, violence against women, constitutional equality, and promoting diversity, ending racism, lesbian rights and economic justice, with these issues having several sub-issues. The organization went about creating these changes through labourious lobbying, rallies, marches and conferences. NOW focusses on variety of issues deploying multiple strategies, causing it to be an organization in which comprehensive goal was envisaged and performed (Encyclopedia Britannica, 2017).

\section{LOCAL WOMEN ORGANIZATION NETWORKS AND DEVELOPMENT}

Women in towns, villages and settlements were also involved in several activisms at local level. Several local activists protested against the custom of burning brides and widows in India and protected women who have been threatened or hurt by domestic violence. All India Women Conference (AIWC) was an autonomous organization founded in 1927 to enhance women development. According to Desai (2001), All India Women Conference (AIWC), in 1934, introduced a bill of for equality in marriage, divorce and property rights, drew upon national rights discourse. Hence, after independence in 1947, women were granted constitutional equality. However, the Hindu, Islam and other religious communities, retained jurisdiction over family law. Local women activists in refugee camps in Croatia, Guantanamo Bay, India, Liberia, Somalia, Thailand and many other parts of the world were the ones who lobbied for justice, ran soup kitchens, educated the children and cared for the family. In the same vein, local women activists in Croatia, Bosinia-Herzogovina and Serbia held peace vigils and marched across front lines to face soldiers and took home sons and fathers involved in the battles. Women in Serbia ran Rape-crisis Centres for women of Bosinia-Herzogovina and organized protests against leaders of their countries who perpetrated wars. Local women activists in Fuji set up the Suva Crisis Centre for women to live when violated through battery, rape and other forms of violations (Commonwealth of Learning, 2000). Women's groups function in so many different ways and the definitions of an organization and a network become blurred. 
In Santiago, Chile, during the long years of dictatorship (1972-89), women's groups organized for the right to democratic elections and women's equality in decision making positions in government. Beginning with a few established women's groups, protest marches were organized for each 8 March (International Women's Day). Momentum grew each year, with many thousands of women from every walk of life marching through the streets of Santiago or gathering in the sports stadium, demanding democratic rule and equality of opportunity for women. Individual women courageously approached soldiers and police in the streets and shouted "Give us back our country!" (Commonwealth of Learning, 2000). When democratic rule returned to Chile, credit was given in large part to the relentless activism of women's groups, and the new government appointed women to positions of power and authority. In Ahmedebad, India, women's work in the informal sector received little recognition and, therefore, little was done to make these women's livelihoods more economically sustainable. Within the trade union movement, Ela Bhatt tried to push forward the cause of these women but had little success. She decided to form a breakaway union for self- employed women; those who work at home or within women's groups rather than in factories or other businesses who had hard time making ends meet. The Self Employed Women's Association (SEWA) was the result. It now has many thousands of members and maintains a type of revolving bank. All the members donated small amount of money each month, and fund was available when they needed it to purchase equipment or set up a small business. Women around the world often cited, and tried to emulate, SEWA's example (Commonwealth of Learning, 2000).

From a small village at the foot of Mount Meru, Kenya, generations of women traveled each day down a large hill to collect water and carry it back up the hill for use in the village. Some days, a woman would make several trips to the river below, carrying heavy pots full of water on her head as she strained up the slippery path to the village. One day, at a meeting of the village women's group, the women decided that enough was enough. They did not want their daughters to suffer as they did, with bent backs and endless pain in their old age. Offering their savings from work in nearby tea plantations, they asked the men to buy water pipes when they went to town one at a time over a period of years. An expert from the Food and Agriculture Organization was approached to assist in setting up a simple pump at the foot of a waterfall in the river. Slowly, the women laid the pipes. Up the hill the pipes went, branching off at each woman's hut. Then large plugs were made of corklike materials and inserted into the pipes, and finally the pump was started. This made every woman in that village to have her own water supply, which had not only improved the health and well-being of the village but also ensured that future generations of girls and women will not have to damage their backs and live in pain from carrying heavy pots on their heads up the mountain daily (Commonwealth of Learning, 2000).

In Suva, Fiji, the newly established YWCA decided to open multi-racial kindergartens. At that time, all education in the country was segregated by language, with Fijian children attending Fijian-language schools, Indian children attending Hindi-language schools, and children of expatriates (from Australia, New Zealand, and the United Kingdom) attending Englishlanguage schools. The facilities and standard of education were vastly different in each type of school, with the English-language schools having the most advanced facilities and teaching. Although much could be said for maintaining the cultures and traditions of each linguistic group, in reality, children in the non-English schools were receiving poorer education, diminishing their future career prospects. In keeping with its long-time principle of ensuring equal opportunity, the YWCA began multiracial kindergartens, open to all children. The effect was dramatic. Educationalists came from all over the country to observe the experiment. There was considerable doubt about the wisdom and propriety of the project. The time came when several Fijian and Indian parents wanted their children to attend the better equipped and 
better staffed European primary school. The YWCA asked the Education Department whether this was possible. A top-level meeting was called. Clearly, this had been a racial and not a linguistic matter before, however, the authorities were faced with making a precedent setting decision. Despite much controversy, the decision came down that any child could attend the European school if they passed an English-language test. All the children passed and were accepted. The schools in Fiji were later multi-racial and this became the official policy of the country. English, Fijian, and Hindi were Fiji's official languages, and all official documents and materials were printed in each of these languages (Commonwealth of Learning, 2000).

Women's Rights and Empowerment Network (WREN) (2019) focus was advancing workplace policies that allows mothers and families to maintain economic stability while caring for their personal health and the health of their family members. In Nigeria, several women Non-Profit Organisations and Non-Government Organisations at local level had improved and developed the lot of many women through health, education, material and social project initiatives.

\section{CHALLENGES FOR WOMEN IN SOCIAL AND ECONOMIC DEVELOPMENT}

The success of women's movement or organisations have met with an antifeminist backlash which called upon familial, communal, cultural and religious identities to try to push back women's gains Karmar (1995).

The mistrust of women's movement of state as an economic support for women and the desire to set their own independent agenda may have contributed to tension between the women's liberation movement and other contemporary social movements. For instance, women of colour, lesbians and working class women organized their own women's movements (JohnsonOdim, 1991).

The common language and philosophy of rights have facilitated cooperation and mutual progress among the various human right movements. However, some groups have criticized the women's rights movements because they were willing to reform the existing system rather than pushing to uproot the structures of inequality in the family and society (International Encyclopedia of Marriage and Family, 2003).

Attention has narrowly focused on ensuring the equal access of girls to primary education. Inequality of access to secondary and higher education persists, low engagement of girls in the study of science and technology has limited the future life and employment options of adolescent girls. The investment in the human capital, health and education, of women and girls was presented as a key way forward. There was the logic that educated and healthy women were more able to engage in productive activities, find formal sector employment, earn higher incomes and enjoy greater returns to schooling than uneducated women (WBGDG 2003).

The willingness to attend school, feed, and provision of healthcare to girls was far more strongly determined by income and the costs of providing these services than was the case for boys. Sen (1990) "100 million missing women" was testimony to how girls were discriminated against in terms of the allocation of household resources to the point that it created a gender imbalance in some societies and countries. Families were often unwilling to invest in the education of girls if this investment was not perceived as bringing them direct economic gains. Girls were valued only as wives and mothers and/or marriage which transferred any potential future gains from these investments to another family. One in 7 girls get married before the age of 18 in the developing world. Early and forced marriage remained the key challenge and 
important factor limiting young women's engagement in both education and economic activities (UNFPA 2012).

According to UNPFII (2013), justice institutions, from the police to the courts, continue to deny women's right to justice. Women and girls remain unable to access justice, given that in many countries there are still laws that discriminate against women in relation to the family, property, citizenship and employment. Justice systems also do not meet the needs of specific groups of women, such as indigenous women who are discriminated against and face violence in the public and private spheres based on both gender and race. In rape situations, justice system did not protect the rights of the survivors as most of them appeared not vindicated nor protected which often led to reprisal by the perpetrators. This seemed to prevent victims from reporting incidents of rape.

Also, cultural factors limited women's rights and engagement in the workplace. Religion had a key role to play in determining gender norms in many cultures and fundamentalist views across the spectrum of religions threaten or deny women's rights, including rights related to sex, sexualities, mobility and employment.

Economic fundamentalism, policies and practices that made profits to have privilege over people, also deny women their rights as workers to work. Though, political culture was important for bringing change, women continued to have limited voice at the local and national levels. Women were not able to fully participate in formal systems of power.

In the majority of cultures, unequal gender and generational relations existed within households with the male head having high level of control. A woman going out to work was often read by others as meaning that her husband was unable to provide for his family, making men reluctant to let their wives work and thus limiting women's engagement in paid work through violence or the threat of violence. When women did engage in paid work, it could improve their voice in the home and their ability to influence household decision-making. It could also lead to conflict in the home, especially if women earned more than men, or women's employment coincided with men's unemployment. In the last decades, a crisis in masculinity has been recognised, relating to the changes in men's roles and positions through processes of globalisation, suggesting a need to focus attention on men if these changes are to bring transformative progress towards greater equality, rather than further harm women (Commonwealth of Learning, 2000).

Women continued to suffer limited mobility and in some cultures, women were not able to leave the home if not accompanied by men, effectively negating any type of paid employment. Even when women were allowed to leave, they may face verbal, sexual and physical abuse from unknown males for being in the street and face gossip and stigma within their own communities. The growing levels and extremes of violence against women have been captured in the notion of femicide - the killing of women by men just for being women, including 'honour killings.' In Mexico for example, the term femicide has been used to describe female factory workers being killed for going against gender norms and engaging in paid work outside the home. One in three women across the globe experience violence at some stages in her lifetime. Violence against women and girls, or the threat of violence, be it physical, sexual or emotional, both in the private and public spheres, at the hands of known and unknown men, remained a key limiting factor to women's mobility and engagement in processes of development. 
Women who work at home have limited opportunities. While women are also engaged in agriculture, this is generally subsistence rather than cash crops. It is estimated that women own only $1 \%$ of property and lack rights to inherit or own land, which severely limits women's engagement in larger scale cash crop production. Even when women can inherit land, the need for male protection or labour may mean they would give the land to male relatives. Lack of land ownership may also stop them from participating in schemes to improve agricultural output, while lack of wider assets disallowed them from accessing loans. Given their lower asset base, women farmers may be most affected by climate change, and while having knowledge of how to adapt, they may be least able to adopt appropriate adaptation strategies (Commonwealth of Learning, 2000).

It is important to remember that policies to promote economic development that include women but did not tackle the structural inequalities at the basis of their exclusion may bring growth gains, but would not necessarily bring gender equality gains. Women's groups and movements continued to be fundamental to promoting women's rights, but many find themselves under threat. Sexual and reproductive rights were critical for social and economic development. Without these rights, women and adolescent girls could not make decisions around fertility. Repeated childbirth kept them from income generating activities and reduced productivity, early and forced marriage that kept young women from education and employment.

Sexual, emotional and physical violence and the threat of violence limited women's mobility, confines women to the home and kept them from engaging fully in processes of social and economic development. Threats to women's rights existed on many levels, including those posed by culture, religion, and tradition, as well as processes of globalisation and economic change. A right gained was not a right maintained unless there was constant monitoring of rights.

Women's responsibility for unpaid domestic work made them poor as well as more economically dependent on men, yet, it was vital for ensuring a healthy and productive workforce. While investment in infrastructure such as water, sanitation and electricity was important to ease the time burden associated with these tasks, it did not change how unpaid work and the care economy was defined and valued. Financial, environmental and health crises intensified the need for care services with the care burden falling disproportionately on women and girls. These numerous challenges have not helped women development. In view of these challenges, the progress made in women development appeared slow.

\section{CONCLUSION}

The three waves of feminism and women's movements' numerous contributions to freedom and development of women had been extensively discussed. The first to third Waves were part of larger social movements that fought for the wome's civil rights and they were thus different from the trickles of activities that came later. But there was cultural transformation that was harvested from the Second Wave's ideas and revolution was the social movement of today. Likewise, the Fourth Wave's deployment of social media had once again transformed politics, feminism and women development. It could be said that the Fourth Wave existed because it said that it existed. It was believed that the Fourth Wave mattered, because their generation mattered. Due to media advances and globalization, waves of mass change came faster and faster. The waves were all part of the same body politic known as feminism and combined to become a powerful and distinct force. The waves have contributed to women being able to play their parts in the improvement of their lives in the area of voting rights, higher education and health care for all, recognition of women's property rights, child rights acts, use of 
contraceptives by willing couples and singles. The waves have enhanced women's participation in politics and recognition of women in the societies of the world, though, we were not where we should be yet as far as women and men equality and equal rights were concerned.

The various international, regional, national and local women movements' contributions to women development have been enumerated. The various women movements contributed and enhanced women's participation in politics and development of their countries. Women movements' efforts gave birth to the Commission on Status of Women, Commission on Human Rights, various sensitizations on women issues/concerns and rights, trainings at national and local levels and better education and schools. Many technologies that made life and chores easier for women were developed. A lot of women were able to move into the forefront of development resulting from debates by women movements all over the globe. Also, women movements/Networks overcame discrimination in educational processes in many parts of the world where such occurred, the media provided information about women's concerns and people became informed about the need for women's rights and equality with men under the law. Newsletters were published about women's issues, needs and voices. Many women movements established Resource Centres, Crisis Centres and Refugee Centres and other facilities for women who needed them, women lawyers were strengthen in their efforts to end all forms of violence against and violations of women among other developmental feats. Women's groups and movements across the globe continued to promote as fundamental the need to respect and defend women's sexual and reproductive, health and other rights.

\section{RECOMMENDATIONS}

Women's socially constructed altruistic behaviour means that economic resources that enter the household through women were more likely to be spent on household and children's needs. Care needed to be taken to ensure that programmes serve women's needs and women are not merely placed at the service of policy agendas.

Educated women are more likely to invest in the education of their own children, and they are also more likely to have fewer children. Thus investment in human capital has positive short and longer term outcomes and is good for both productivity gains that were limiting unsustainable population growth. Women and men should be well educated for total human and societal development.

Men and boys can have roles to play in the prevention of gender based violence and the promotion of gender equality. So, they should be fully sensitized against gender based violence and be involved in programmes to prevent gender-based violence and enhance gender equality that could enable both males and females to utilize their full potentials for National development.

There is a need to strengthen women's access to both formal and informal justice systems, and ensure that these are responsive to advancing all women's equal rights, opportunity, and participation. Improving women's political voice is also crucial to women and human development.

Policies to provide affordable, quality child care and adequate healthcare services would not only free women to enter paid employment, but change care work from being understood as a domestic responsibility to a collective responsibility. This change in how care work is conceptualized and valued should be a longer-term goal. 
In the short term, there is a need to create full, decent productive employment opportunities for women and access to finance, as well as continue to provide social protection, and more importantly promote and value women as good with money. Promotion of women's economic rights is very essential for economic growth. This entails promoting a range of women's rights: their sexual and reproductive rights and rights to education, to mobility, to voice, to ownership, and to live free from violence.

Countries of the world that are yet to fully implement the endorsed international, regional and national policies on gender mainstreaming, gender equality, justice and equity, women empowerment, gender based violence, human rights, women rights, land and property rights' acts, child's rights, education and health for all should do so. If these were done, life would become easier for men, women and humanity in general. There would be all round development for children women and men.

\section{References}

Abdullahi, H. (1995). Wifesm and activism: The Nigerian women's movement, In the challenge of local feminism, women's movements in global perspective, ed. A Basu Boulder and Co: Westview Press.

AlpízarDurán, L. (2010). The implementation of the Beijing Declaration and Platform for Action, the outcomes of the 23rd special session of the General Assembly and its contribution to shaping a gender perspective towards the full realization of the MDGs, Keynote speech at High-Level Roundtable at the 54th session of the UN Commission on the Status of Women, United Nations Headquarters NY, March.

Alvarez, S.E. (1990). Engendering democracy in Brazil, women's movements transitive Princeton, N. J: Princeton University Press.

Australian Electoral Commission (2011). Women and the right to vote in Australia. 28 ${ }^{\text {th }}$ January.

AWID (2012). Getting at the Roots: Re-integrating human rights and gender equality in the post-2015 development agenda. Association for Women's Rights in Development, October.

Baumgardner, J. and Richards, A. (2000). Manifestation: Young women, feminism and the future. New York: Farrar, Straus and Giroux

Baumgardner, J. (2011). F'em: Goo goo, gaga and some thoughts on balls, USA: Perseus Books Group Seal Press

Brunell, L. (2008). Feminism re-imagined: The third wave, Encyclopedia Britanica Book of the Year. Chicago: Encyclopedia Britanica International.

Commonwealth of Learning (2000). Theoretical perspectives on gender and development eds, Parpart, J. L, Connelly, M. P. \& Barriteau, V. E. Canada, International Development Research Centre.

Chant, S. (2006). Re-thinking the "feminization of poverty" in relation to aggregate gender indices. Journal of Human Development, (7 (2): 201-220.

Chant, S. (2008). The "feminisation of poverty" and the "feminisation" of anti-poverty programmes: Room for revision? Journal of Development Studies (44 (2): 165-197.

Cochrane, C. (2013). The fourth wave of feminism: Meet the rebel women, The Guardian, United Kingdom.

Cott, N. F. (1987). The grounding of modern feminism. New Haven: Yale University Press.

Desai, M. (2001). India, women's movements from nationalism to sustainable development, In women's rights: A global view, ed, I. Walter. Westport, Ct: Greenwood Press.

Development Alteernatives for Women for a new Dawn (DAWN) (2019). Equality, quality and accountability in advancing sexual and reproductive health rights (SRHR) in China, India and Indonesia. https//dawnnet.org. Retrieved November, 6th.

Dollar, D and Gatti, R. (1999). Gender Inequality, Income, and Growth: Are Good Times Good for Women? Gender and Development Working Papers, (1), May.

Dooling, A. D. (2005). Women's literary feminism in the twentieth-century China. China: Macmillan press

Dubois, E. C. (1979). Harriot Stanton Blatch and the winning of women suffrage, New Haven, Conn: Yile University Press. 
Echols, A. (1989). Daring to be bad: Radical feminism in America, 1967-1975. Minneapolis: University of Minnesota Press.

Encyclopedia Britannica (2017). National Organisation for Women. www.britannica.com. Retrieved January $21^{\text {st. }}$. Faludi, S., (1992). Blacklash: The undeclared war against women, London: Vintage.

Flexer, E. (1996). Century of struggle: The women's rights movement in the United States, USA: The Belknap Press Freeman, E. B. (2003). No turning back: The history of feminism and the future of women, Ballantine Books : 464

Friedan, B. and Murray, P. (2020). Founding National Organisation for Women (NOW). https://now.org. Retrieved January, $14^{\text {th }}$.

Gillis, S., Howie, G., Munford, D. (2007). Third wave feminism: a critical exploration. Basingstoke: Palgrave Macmillan Press.

Goldstern, L. (1982). Early feminist themes in French Utopian socialism: The St. Simonians and Fourier, Journal of the History of Ideas, 43 (1).

Hanisch, C. (2006). Hanisch, New introduction to "The personal is political"-Second wave and beyond, Archived from the original.

Henry, A. (2004) Not my mother's sister: Generational conflict and third-wave feminism, Bloomington: Indiana University Press.

Holzmann, R. and Jørgensen, S (2000). Social Risk Management: A new conceptual framework for social protection and beyond, Social Protection Discussion Paper Series 0006, Social Protection Unit, Human Development Network, The World Bank, February.

Holt, D., Cameron, D. (2010). Cultural strategy: Using innovative ideologies to build breakthrough brands, Oxford: Oxford University Press

Hooks, B (2000). Feminism is for everybody: Passionate politics. Pluto Press.

Humm, M. (1995). The dictionary of feminist theory. Columbus: Ohio State University Press.

International Encyclopedia of Marriage and Family (IEMF) (2003). Women's movement, Great Britain: Gale Group Inc.

Johnson-Odim, C. (1991). Common themes, different contexts: third world women and feminism, In third world women and politics of feminism, ed, C. T. Mohanty, A. Russo, and I. Torres, Bloomington: Indiana University Press.

Klasen, S. (1999). Does Gender Inequality Reduce Growth and Development? Evidence from Cross-Country Regressions, Gender and Development Working Papers, (7), November.

Ko,D., Haboush, J. K., Piggott, J. .R. (2003). Women and Confucian cultures in premodern China, Korea and Japan, University of California Press.

Krolokke, C., Sorensen, A.S. (2005). Three waves of feminism: From suffragettes to girls. Gender communication theories and analyses: From silence to performance. Sage: 24

Kruseman, M. (1984). Dutch feminist pioneer Mina Kruseman in a letter to Alexandre Dumas-in: Maria Grever, Strijd tegen de stilte and Johanna Naber (1859-1941), en de vrouwenstem in geschiedenis (Hilversum).

Kumar, R. (1995). From chipko to sati: The contemporary Indiana women's movement, In the challenge of local feminisms, women's movements in global perspective, ed. A. Basu Boulder, Co: Westview Press.

Lamb, S. (2009). Feminist ideals for a healthy female adolescent sexuality: A critique, Sex Roles 52 (5-6): 294-306

Merrian-Webster's (2003). Collegiate dictionary, Encyclopedia Britanica Company 11 th Edition.

Messer-Davidow, E. (2000). Disciplining feminism: From social activism to Academic discourse. Durham, N.C.: Duke University Press

Molyneux, M. (2007). Two cheers for conditional cash transfers, IDS Bulletin (38 (3): 69-75.

Molyneux, M. (1985). Mobilization without emancipation? Women's interests, the state, and revolution in Nicaragua, Feminist Studies 11 (2): 227-254.

Moser, C. (1989). Gender planning in the Third World: Meeting practical and strategic gender needs, World Development, 17 (11): 1799-1825.

Nelson, J. (2011). International Women Day: A century to celebrate. History working online, August. 
Offen, C. (1987). Les orignes des mots “feminisme' et 'feminite”Revue d'histoire modern et contemporaine. JulySeptember.

Okonjo, K., (1994). Reversing the marginalization of the I visible and silent majority: Women in politics in Nigeria, In women and politics worldwide, ed. Nelson, B. J. and Chwdhury, N. New Haven, CT: Yale University Press.

O'Neill, W., L. (1969). Everyone was brave: The rise and fall of feminism in America, Chicago; Quadrangle Books.

Ogundana, C. F. (2015). Feminist Theories and frameworks, Unpublished Mimeograph, Ekiti State University, AdoEkiti

Philips, M. (2004). The ascent of women: A history of the suffragette movement and the ideas behind it, Abacus : 1-370.

Pond, J. (2011). Women's history: Three waves of feminism. GWS 201. www.slideshare.net

Rampton, M. (1914). The three waves of feminism, Portland: Pacific University Centre for Gender Equality.

Ruether, R. R. (2012). Women and redemption: A theological history (2nd ed.) Minneapolis: Fortress Press.

Rupp, L. and Tailor, .V. (1987). Survival in the doldrums: The American woman's rights movement, 1945 to the 1960s, New York: Oxford University Press

Sen, A. (1990). More than 100 million women are missing, New York Review of Books 37 (20).

Snyder, R. C. (2008). What is third-wave feminism? A new directions essay, Journal of Women in Culture and Society: 34 (1): 175-196.

Stevens, D. and O' Hare, C. (1995). Jailed for freedom: American women win the vote, Troudale, OR: NewSage Press

Sydney Morning Herald (1943). International Women's Day Celebration. $8^{\text {th }}$ March, Newspaper.com

UNFPA (2012). From Childhood to Womanhood: Meeting the Sexual and Reproductive Health Needs of Adolescent Girls. Fact Sheet: Adolescent Girls' Sexual and Reproductive Health Needs.

UNPFII (2013). Study on the extent of violence against women and girls in terms of article 22(2) of the United Nations Declaration on the Rights of Indigenous Issues (E/C.19/2013/9).

Walker, R. (1992). Becoming the third wave, Ms : 39-41

Walker, R. (1995). To be real: Telling the truth and changing the face of feminism, New York: Anchor Books Walter, I. (2001). Denmark: Women's rights and women's welfare, In women's rights: A global view, ed. I. Walter, Westport, Ct: Greenwood Press.

Warner, M. (1999). Emmeline Pankhurst-Time 100 people of the Century. Time Magazine, June, 14th

West, I. (1999). The United Nations women conference and feminist politics, In gender politics in global governance, ed. M. K. Meyer and E. Prugl, London: Rowman and Littlefield.

Wheeler, M.W. (1995). One woman, one vote: Rediscovering the woman suffrage movement, Troudale OR: NewSage Press

Whelehan, I. (1995). Modern feminism thought: From the second wave to "Post-Feminism, Edinburgh: Edinburgh University Press.

WBGDG (2003). Gender equality and the millennium development goals, World Bank Gender and Development Group, April 15

Women's Rights and Empowerment Network (WREN) (2019). A playbook for advancing gender equality. South Carolina. Scwren.org

World Bank (2001a). Social protection strategy: From safety net to springboard, Washington DC: USA.

World Bank (2001b). Engendering development through gender equality in rights, resources, and voice, New York: Oxford University Press.

World Bank (2002). Integrating gender into the World Bank's work: A strategy for action. Washington DC: USA. 